This is the post print version of the article, which has been published in International Journal of Human Resources Development and Management. 2019, 19(1), 5-20.

https://doi.org/10.1504/IJHRDM.2019.097060

\title{
Stakeholder Engagement in a Non-Profit Organisation: An Issue-Based \\ Perspective
}

\author{
Anna Heikkinen* \\ University of Tampere, Faculty of Management \\ FI-33014 University of Tampere, Finland \\ Email: Anna.L.Heikkinen@uta.fi
}

\section{Johanna Kujala}

University of Tampere, Faculty of Management

FI-33014 University of Tampere, Finland

Email: Johanna.Kujala@uta.fi

\section{Maria Inha}

University of Tampere, Faculty of Management

FI-33014 University of Tampere, Finland

Email: maria.inha7@gmail.com

*Corresponding Author

\begin{abstract}
The aim of this study is to gain insight into stakeholder engagement in a non-profit network organisation; it contributes to the literature on collaborative and cooperative understanding of stakeholder engagement by presenting an issue-based perspective in a non-profit organisation. The research is conducted as a qualitative case study, and multiple data sources
\end{abstract}


are used to examine stakeholder engagement in the case organisation from two perspectives: 1) stakeholders and stakeholder relationships, and 2) the issues and their salience as advocated by the stakeholders. It concludes that non-profit network organisations depend on their stakeholders for various resources. Because the continuation of a non-profit organisation is fully dependent on the support of its stakeholders, it can be viewed as an ultimate stakeholder organisation; here, joint activities create value for all parties involved, and the organisation practically exists through its stakeholders. These conclusions contribute to the stakeholder literature by extending the models to include non-profit organisations.

Keywords: stakeholder theory, stakeholder engagement, issue-based approach, nonprofit organisations, networks, case study

Biographical notes:

Dr. Anna Heikkinen holds a $\mathrm{PhD}$ in Management and Organization studies from the University of Tampere, Finland, where she currently works as a post-doctoral researcher. Her research interests include corporate sustainability, stakeholder theory, and discourse analysis. Her work has been published in edited volumes and international journals, such as Journal of Business Ethics, Business Communication Quarterly, and International Journal of Knowledge Management Studies.

\section{Johanna Kujala}

Dr. Johanna Kujala is a Professor of Management and Organization at the University of Tampere, Faculty of Management. She has an extensive teaching and supervising experience that covers courses at all university levels as well as adult and continuing education. She has published over 40 scholarly articles in international peer-reviewed journals and volumes. She is a member of the Executive Committee of European Business Ethics Network and a 
member of the review boards of Journal of Business Ethics and Business Ethics: A European Review. Her current research interests focus on stakeholder engagement and value creation, moral decision-making, and case studies on corporate responsibility and sustainability.

\section{Maria Inha}

Maria Inha holds a Master's degree in Business Administration majoring in Responsible Business. She is currently working as a Digital Service Manager with HR service development and analytics at Barona, Helsinki, Finland.

This paper is a revised and expanded version of a paper entitled 'Managing Stakeholder Relationships: A case study of a non-profit network organisation’ presented at International Conference for Management Cases (ICMC), Greater Noida, India, 1-2 December 2016.

Disclaimer: This case is written for classroom discussion and is not intended to illustrate either effective or ineffective handling of an administrative situation, or to represent successful or unsuccessful managerial decision-making, or endorse the views of the management. The authors may have disguised/camouflaged some of the names, events, financial and other recognisable information to protect the identity of individuals and confidentiality behind decision-making. If the study uses secondary data, and information (news reports, published papers, books, reports available on the company website) the sources have been cited wherever such data and information have been used. The views and opinions expressed in this article are those of the authors. 


\section{Introduction}

In the post-industrial world, societal and economic development favours collaboration over control and co-creation over competition. Organisations are no longer isolated and autonomous hubs of wealth and knowledge creating products and services for other organisations and individuals - rather, they are parts of networks that contribute to common wellbeing. Consequently, the idea of profit maximisation is being replaced with the ideas of stakeholder collaboration, value co-creation and corporate responsibility (Carroll, 2016; Freeman, 2010; Harrison and Wicks, 2013; Myllykangas, Kujala and Lehtimäki, 2010). In a networked society, organisations work in close collaboration with other organisations and individuals; they operate in and affect their environment as well as are shaped by it. To understand how such organisations and networks function - and how organisational goals may be achieved in these circumstances - we need to understand the roles and interests of different stakeholders as well as the overall context.

The growing emphasis on sustainable and democratic development around the globe has brought the roles of voluntary, non-profit organisations (NPOs) and non-governmental organisations (NGOs) under scrutiny in the realm of global governance. In the last two decades, such organisations have played an important role in engaging business society in sustainable and ethical practices. As a contrast to business organisations focusing on profit generation, the main goals of NPOs comprise moral or political causes (Hasnas, 2013). The number of NPOs and NGOs has increased substantially in recent decades along with their power and overall influence, and they have become important actors in promoting sustainability, corporate responsibility, collaboration and co-value creation in the business community (Arenas, Lozano and Albareda, 2009; Skouloudis, Evangelinos and Malesios, 2015). 
Stakeholder theory has been offered as a way to understand how organisations function and collaborate with other organisations and individuals. The concept of a stakeholder first appeared in the 1960s in North American and Scandinavian management literature (Freeman, Harrison, Wicks, Parmar and de Colle, 2010; Strand and Freeman, 2015; Näsi, 1995). The most commonly known conceptualisation of a stakeholder is presented by Freeman (1984, p. 46), who defines a stakeholder as 'any group or individual who can affect or is affected by the achievement of the organization's objectives'. In recent decades, the stakeholder approach has become one of the most prominent frameworks for studying business organisations and the role of business in society (Agudo-Valiente, Garcés-Ayerbe and Salvador-Figueras, 2015; Harrison and Wicks, 2013; Kujala, Lämsä and Riivari, 2017; Midtun, Gautesen and Gjolberg, 2006; Mitchell, Agle and Wood, 1997; Plaza-Úbeda, Burgos-Jiménez and Carmona-Moreno, 2010).

The stakeholder approach moves the focus from trade-offs to collaborative value creation (Freeman, 2010); hence, it is well suited to the study of stakeholder engagement in NPOs. However, NPOs function on different grounds and goals than business organisations; therefore, their key stakeholders differ from the typical stakeholders of a business organisation (Leroux, 2009; Roloff, 2008). Yet, the majority of scholars have focused on developing a stakeholder approach to business management, whereas examinations of stakeholder theory from the perspective of NPOs have been scarce. Moreover, stakeholder analysis on NPOs and NGOs often only identifies a limited number of important stakeholders. For instance, Leroux (2009) identifies clients and financiers as the key stakeholder groups of NPOs but does not depict or analyse the relationships further. The scarcity of studies on stakeholder engagement and the relationship management of NPOs and NGOs represent a research gap with an important phenomenon worth examining. 
The purpose of this study is to examine stakeholder engagement in an NPO. Here, stakeholder engagement refers to the idea that stakeholders are entitled to have input into the matters that affect them, and that organisations undertake various actions to involve stakeholders in a positive manner in their activities (Dawkins, 2014; Greenwood, 2007). This study builds on recent developments in stakeholder research, focusing on stakeholder engagement that emphasises collaboration and cooperation among stakeholders instead of instrumental stakeholder management (Derry, 2012; Heikkinen, Kujala and Lehtimäki, 2013). Stakeholder research has presented multiple approaches to stakeholder engagement, but only a few studies have focused on NPOs (Laasonen, 2010; Leroux, 2009; Skouloudis et al., 2015).

In this research, the case organisation is an NPO: the European Business Ethics Network (EBEN). As a long-standing and established network of business ethics academics and practitioners, EBEN provides a unique case to examine the activities and stakeholder engagement of an NPO. This research follows a qualitative case study strategy, and multiple sources of data are used to provide rich and contextual insights into the case. The empirical data consist of the organisation's internal documents, semi-structured interviews, stakeholder maps and open-ended survey data. Stakeholder engagement in the case organisation is examined from two perspectives, focusing first on stakeholders and stakeholder relationships and second on the issues advocated by the stakeholders as well as the salience of these issues.

This study contributes to previous literature by shedding light on the scarcely researched phenomenon of stakeholder engagement in NPOs. The findings propose that in the case of an NPO, the organisation largely depends on its stakeholders for various critical resources. In addition, an NPO can be viewed as an ultimate stakeholder organisation, where the organisation's and its stakeholders' objectives are intertwined and joint activities create value for all involved parties. 
The remainder of the article is structured as follows. First, previous literature on stakeholder identification, engagement and stakeholder issues is discussed. Next, the case organisation, empirical data and data analysis process are presented. This is followed by a presentation of the findings related to stakeholders, stakeholder relationships and stakeholderadvocated issues. Last, a discussion and conclusions with contributions and suggestions for future research are given.

\section{Theoretical Background}

Stakeholder theory argues that an organisation's success depends on the support of the groups that have an interest in and influence over the organisation's actions (Freeman, 1984). The theory focuses on an organisation's effects on its stakeholders and the effects of these groups on the organisation, as such groups have 'a stake' in the organisation and thereby contribute to its activities (Näsi, 1995). The stakeholder approach emphasises that organisations operate as part of a stakeholder network, which comprises multiple interconnected actors. The approach can be characterised by elements of morality and utilitarian conduct, and it emphasises that the organisation is not necessarily a focal point to which all stakeholders connect, but rather that it is one link in a larger grouping of actors (Freeman, 1984; Post, Preston and Sachs, 2002; Wheeler, Colbert and Freeman, 2003). Concisely, stakeholder theory supports the idea that an organisation has multiple objectives that depend on the interests of different stakeholders.

The underlying objective of applying the stakeholder approach to organisational activities is to legitimise the organisation's actions, create value with and for stakeholders and ensure the success of the organisation's operations through stakeholder engagement (Freeman, Harrison, Wicks, Parmar and de Colle, 2010; Harrison, Bosse and Phillips, 2010; Sachs and Rühli, 2011). The idea behind stakeholder engagement is that stakeholders are 
entitled to have input into the matters that affect them; therefore, organisations undertake various actions to engage with their stakeholders (Dawkins, 2014; Greenwood, 2007). According to Freeman (1984), the process of stakeholder engagement may be examined through a three-level analysis comprising the rational level, where stakeholders are identified; the process level, where stakeholder relationships are evaluated; and the transactional level, where collaboration and cooperation with different stakeholders are developed further.

Freeman's (1984) original conceptualisation of a stakeholder organisation is based on the ties between the focal organisation and its stakeholders, as presented in Figure 1. These ties represent the relationships between the actors, suggesting that they are mutually dependent on one another (Donaldson and Preston, 1995; Freeman and Evan, 1990). The relationships, however, are not always based on mutual consent (Clarkson, 1995; Post et al., 2002). For example, a company's negative environmental impact may cause risks to stakeholders such as the local community and NGOs that might not otherwise wish to engage with the company. Ideally, an effective organisational strategy is primarily a reflection of the key stakeholders’ interests (Donaldson and Preston, 1995; Harrison and St. John, 1996).

$<$ Insert Figure 1 here $>$

Mainardes, Alves and Raposo (2012) examine public sector stakeholder relationships and present a typology of six classifications of stakeholders: regulator, controller, partner, passive, dependent and non-stakeholder (Figure 2). In Figure 2, the direction and strength of influence are symbolised by the direction and thickness of the arrows. Mainardes et al. (2012) suggest that relevance, mutual influence and participation are essential factors in determining the nature and strength of relationships. 
Approaches to stakeholder relationship analysis increasingly rely on evaluating the importance of various issues within these relationships (Bundy, Shropshire and Buchholtz, 2013; Roloff, 2008). Issue-based stakeholder analysis highlights the issues advocated by different stakeholders as opposed to emphasising the importance of the focal organisation or stakeholder groups. Roloff (2008, p. 238) suggests a new issue-focused definition of a stakeholder as 'any group or individual who can affect or is affected by the approach to the issue addressed by the network'. While traditional stakeholder management is mostly organisation-centric and strives to enhance the organisation's welfare, issue-focused stakeholder engagement aims to address the focal issues that affect the relationships between the organisation and its stakeholders. Thus, issue-focused stakeholder management considers the examination of different issues an organisation faces as an important step in stakeholder engagement (Roloff, 2008).

According to Freeman (1984), stakeholder issues may be identified and their importance evaluated with the help of an issue matrix. The simplified matrix presented in Figure 3 combines the level of concerns of the key stakeholders with the different issues; it serves as an instrumental tool in acknowledging the most salient stakeholder issues.

$<$ Insert Figure 3 here $>$

Stakeholder issue salience can be divided into two categories: instrumental and expressive. Instrumental salience refers to the strategic importance of the issue, whereas expressive salience means the organisation's willingness to engage with the issue to express its identity (Bundy et al., 2013; Rowley and Moldoveanu, 2003). Stakeholder relations that 
are based on issues related to identity such as political, social or ethical causes may be sounder and stronger than merely economic connections (Crane and Ruebottom, 2012; Rowley and Moldoveanu, 2003).

Based on the idea of expressive and instrumental salience, Bundy et al. (2013) created the issue salience framework (Table 1). In this framework, stakeholder issues are evaluated in relation to two dimensions: 1 ) expressive salience (i.e. the issue's relationship with the organisational identity), and 2) instrumental salience (i.e. the issue's relationship with the strategic frame of the organisation). The issues may be evaluated as consistent (or positive), conflicting (or negative) or unrelated on both of these dimensions (Bundy et al., 2013). As a result of this evaluation, the issues are divided into three categories: substantive issues, symbolic issues and nonissues. Substantive issues are of the highest salience, as they are either consistent or conflicting in terms of reflecting both instrumental and expressive salience elements. Symbolic issues represent moderate salience, as they are unrelated to either instrumental or expressive salience whilst being consistent or conflicting with the other one. The issue salience framework is presented in Table 1.

$<$ Insert Table 1 here $>$

As presented in Table 1, substantive issues are further divided into four categories. First, issues that are consistent with both expressive and instrumental salience offer a true opportunity for the organisation. Second, issues that are conflicting with both expressive and instrumental salience pose a true threat to the organisation. Third, issues that are consistent with instrumental salience but conflict with expressive salience may pose an identity conflict to the organisation. Fourth, issues that are consistent with expressive salience but conflict with instrumental salience may pose a frame conflict to the organisation. 
Similarly, symbolic issues can be divided into four categories. First, if the issue is consistent with the organisational identity (expressive salience) but unrelated to the strategic frame (instrumental salience), it poses an expressive opportunity to the organisation. Second, if the issue conflicts with the organisational identity and is unrelated to the strategic frame, it poses an expressive threat to the organisation. Third, issues that are consistent with instrumental salience but unrelated to expressive salience pose instrumental opportunity. And fourth, issues that conflict with instrumental salience and are unrelated to expressive salience pose an instrumental threat to the organisation. Finally, issues that are unrelated both to the organisational identity and to the strategic frame of the organisation are called nonissues as they neither pose or offer an instrumental nor an expressive opportunity or threat to the organisation.

To summarise, while there is ample previous research on the identification and classification of organisational stakeholders and stakeholder relationships, stakeholders and stakeholder engagement in the non-profit sector have scarcely been addressed in the literature. In this study, this gap is answered by examining a case of a non-profit stakeholder network.

\section{Research Design}

This study uses an intensive qualitative case study strategy (Eisenhardt, 1989; Yin, 2009) to examine stakeholder engagement in an NPO: the European Business Ethics Network (EBEN). This strategy aims to generate comprehension about the research case from the ‘inside’ by providing contextualised and holistic in-depth description and interpretation (Eriksson and Kovalainen, 2016). While the main interest of a qualitative case study is not to test theoretical propositions, it is essentially theoretically informed and thus capable of generating or extending theory (Eisenhardt, 1989; Eriksson and Kovalainen, 2016). As an 
established network of business ethics academics and practitioners, EBEN provides a unique case to examine the activities of an NPO and contribute to stakeholder engagement theory.

EBEN is a cross-European NPO that aims to generate awareness of ethical global issues and create dialogue on the role of business in society. EBEN was founded in Brussels in 1987 and is currently based in Leuven, the Netherlands. Its main activities include promoting and conducting research on business ethics and related fields as well as distributing knowledge and experience through various types of events for academics and practitioners. EBEN organises two annual academic conferences as well as a doctoral workshop. The network is mainly organised through the EBEN Executive Committee (ExCom) that governs the organisation along with the regional and national networks that conduct the network's activities. EBEN has 18 established national networks: Austria, Belgium, Cyprus, Finland, France, Germany, Greece, Ireland, Israel, Italy, Poland, Portugal, the Netherlands, Scandinavia, Spain, Switzerland, Turkey and Ukraine. While some of these networks operate with a more international focus, others are mostly active on a national level. Therefore, the organisation's stakeholders, such as the national networks and their members, are the network's source of vitality and the main target group for the network's activities.

\section{Data Generation and Analysis}

This study utilises multiple sources of data to describe the case and to understand the different stakeholders involved in the case (Eriksson and Kovalainen, 2016). The data include EBEN's internal documents, interviews with the ExCom members, stakeholder maps and survey data from EBEN's national networks.

The data generation was a multistep process. First, document data were collected to achieve a general insight into the organisation and to provide contextual understanding for the case. This data comprise EBEN's article of association, meeting minutes and material from EBEN's webpages and extranet. Minutes were collected from 16 ExCom, national 
network and general assembly meetings from 2011 to 2013. Next, five interviews were conducted with EBEN's ExCom members. The interviews were conducted via Skype or phone in November and December 2014. A semi-structured interview guide with openended questions (Alvesson, 2003; Eriksson and Kovalainen, 2016) was used to generate insights into EBEN as an organisation, EBEN's activities and EBEN's stakeholders. The interviews lasted between 38 and 67 minutes and were fully transcribed. After the interviews, the interviewed ExCom members were asked to draw a stakeholder map of EBEN to generate further insights into their perceptions of the organisation's stakeholders. The resulting maps (returned to the researchers via email) provided overviews as well as specific details of EBEN's stakeholders. Third, an email survey with open-ended questions was sent to the chairpersons of the 18 national networks in December 2014. The survey focused on the activities and interests of the national networks and on EBEN and its activities. Responses were received from 15 national networks, while one network chose not to participate in the study. As a result, rich and illuminating empirical evidence on EBEN as an organisation, the network's activities and stakeholders and the views of these stakeholders was generated.

The data were analysed using qualitative content analysis. This is a suitable method for text-form data, as it is a systematic and flexible method of reducing and analysing data to create a concise description (Elo and Kyngäs, 2008; Graneheim and Lundman, 2004; Schreier, 2014). The data were transcribed, and then data analysis commenced with reading through the data several times. The data were analysed in two steps: First, the focus was on the stakeholders and stakeholder relationships of EBEN, and the analysis was based on the concepts and frameworks of Freeman (1984) for stakeholder identification and Mainardes et al. (2012) for stakeholder relationships. Second, the analysis focused on examining the issues advocated by the stakeholders as well as the salience of these issues. For this purpose, the theoretical insights from Freeman (1984) on the issue/stakeholder matrix and Bundy et al. 
(2013) on issue salience were used. This analysis allowed for an examination of the stakeholders’ perspectives on current and future stakeholder engagement.

\section{Findings}

The analysis identified four main stakeholder groups. Table 2 summarises these stakeholders, presents the actors belonging to each stakeholder group and identifies the type of relationship the stakeholder group has with EBEN in terms of influence.

$<$ Insert Table 2 here $>$

The 18 independently operating national networks are EBEN's most important stakeholder group - their operations vary greatly depending on their size and level of activity. In general, the national networks can be seen as stakeholders that may assist the organisation's ExCom. For instance, the ExCom presents its strategic plans to national networks prior to presenting them to the general assembly, which is the organisation's decision-making body. The plans are discussed with national networks in search of agreement and support for the initiatives. Moreover, the national networks work to connect local members to the head organisation and conduct activities on a national or regional level. The smaller networks largely depend on EBEN for financial support and organisational structure, while the larger networks are in a controller or regulatory position because they have significant resources related to finance, knowledge and conducting activities (e.g. conferences) that EBEN greatly depends on.

EBEN has over 1,000 members from over 40 European countries. This stakeholder group includes both members that have joined the organisation through a national network and direct members of EBEN Europe. The members can be categorised into individual, 
student, institutional (universities and research institutes) and corporate members. From 2011 to 2013, the corporate and institutional members at most accounted for $15 \%$ of the total number of members. EBEN's annual events, such as conferences and workshops, provide the main forum for interaction among the members. Members can be classified as a controller stakeholder group because they provide significant resources for the organisation (finance, knowledge, etc.), and in turn, they receive tangible benefits from EBEN in the form of an established organisation advocating for their interests and providing an international forum for exchanging knowledge about business ethics.

Similar organisations include other international research-oriented networks focusing on business ethics, corporate social responsibility and related issues, such as the Academy of Business in Society (ABIS), the Society for Business Ethics (SBE), the Academy of Management (AOM) and The European Business Network for Corporate Social Responsibility (CSR Europe). While these organisations may provide opportunities for cooperation as well as for benchmarking, there are notable risks concerning competition over the same resources between members, conference participants and sponsorship from companies. Due to this possible two-way influence, similar organisations may have a controlling influence over EBEN - when EBEN collaborates with other organisations, the organisation can be classified as a partner.

Other stakeholders refer to actors who are not directly involved in or affected by EBEN's activities. These other stakeholders include the media, civil society, the public sector, schools and the European Union (EU). The EU in particular is mentioned several times when discussing EBEN's operational environment as well as future activities in terms of political influence.

\section{Issues Advocated by the Stakeholders}

Seven issues advocated by EBEN’s stakeholders were identified: 1) business ethics 
research, 2) business ethics education, 3) the network as a social hub, 4) financial stability, 5) strengthening EBEN, 6) ethical business conduct and 7) political impact and public awareness.

Business ethics research was identified as a key interest - the stakeholders expressed that organising conferences and supporting academic activities is the most important activity. This issue is also of high importance to the national networks. Business ethics education is closely linked to research, and the stakeholders stressed the importance of maintaining and improving business ethics education in the associated universities. In addition, the issue of applying a more practical approach in teaching was raised. None of the stakeholder groups presented education as a primary issue; rather, they viewed it as something that the network can influence because of the academic expertise and affiliations of its members.

The network as a social hub refers to the opportunities the network provides for its members to meet each other and discuss business ethics. On the whole, the social aspects related to the networks' activities are highly valued by the stakeholders. Financial stability means different things within the network - the smaller national networks may face difficulties in collecting membership fees; thus, it is in their interest that EBEN remains flexible on this issue. The larger national networks discussed financial stability in terms of receiving funding from business and public organisations and having a more profit-oriented focus in the network. Strengthening EBEN was a general theme that was discussed in connection to the other identified issues. The stakeholders posited that EBEN should be strengthened by finalising the network's strategy development as well as by crystallising the network’s objectives.

Ethical business conduct was seen as a potential impact of business ethics research. Stakeholders stated that EBEN could engage with practical business ethics activities by cooperating with companies; however, verifying the ethical conduct of a business was raised 
as something that should be avoided when encouraging businesses to improve their ethicality. Political impact and public awareness were presented as future issues the network should attend to; however, it was acknowledged that this might be challenging due to the network's focus on academic activities. The larger national networks in particular highlighted the notion that EBEN should strengthen its public presence and ties to both regional and EU political actors. It was also noted that there are other actors who are currently promoting business ethics; thus, overlapping activities waste resources.

The salience of each of the identified issues was evaluated for each stakeholder. An issue/stakeholder matrix was compiled (Freeman, 1984), and the level of concern for each issue was analysed using a scale from 1 to 3 ( 1 = low level of concern, $3=$ high level of concern). Table 3 presents the issue/stakeholder matrix.

$<$ Insert Table 3 here $>$

Table 3 illustrates that the smaller networks are more concerned about financial stability in comparison to the larger networks. In contrast, the larger networks are more concerned about ethical business conduct, political impact and public awareness than are the smaller networks. The larger networks are interested in extending EBEN's activities to influencing external business, political and media organisations. Similar organisations were identified as being concerned with business ethics research and education as well as ethical business conduct; therefore, there might be competitive elements in the relationships with these organisations.

The salience of these issues was analysed using Bundy et al.'s (2013) issue salience framework, wherein the issues are examined in terms of their relationship with organisational identity and the strategic frame of the organisation. Table 4 presents the issues according to 
the issue salience framework.

$<$ Insert Table 4 here $>$

Business ethics research, business ethics teaching and the network as a social hub represent true opportunities for organisational development. The issues follow EBEN's current strategic frame and are at the core of the organisation's identity. Financial stability and strengthening EBEN hold great instrumental salience due to the practical strategic actions the stakeholders are interested in. Increasing financial stability is related to the organisation's continuity but is not directly related to its identity. Similarly, strengthening EBEN is related to the strategic issues of improving communication and administrative practices; therefore, these issues are instrumental opportunities. Political influence, public awareness and business ethics conduct are somewhat ambiguous. In particular, the different-sized national networks view these issues in different ways. On the one hand, the issues are seen to conflict with the identity when, for instance, they are seen to compromise the academic focus of the network; thus, these issues are frame-conflicting. On the other hand, the larger networks emphasise these issues as representing the future path for the organisation; therefore, they may also present true opportunities.

\section{Discussion and Conclusions}

This study focused on examining stakeholders and stakeholder relationships in an NPO. It identified the organisation's main stakeholder groups as well as the issues advocated by these stakeholders. Based on the identification of EBEN's stakeholders and the influence of the relationships between EBEN and its stakeholders, it is evident that EBEN greatly depends on its stakeholders for a variety of resources. In particular, the larger national 
networks are an essential source of financial and knowledge resources that enable the organisation to exist. Therefore, it can be concluded that in the case of an NPO organisation, it largely depends on its stakeholders for various critical resources. This conclusion contributes to the literature on stakeholder relationships and engagement by extending the traditional models to include NPOs.

Furthermore, the findings highlight that in addition to analysing stakeholder and stakeholder relationships, it is crucial to examine the issues advocated by the stakeholders. The findings present a variety of issues across the organisation's stakeholder field and discuss their salience. The study shows that the salient issues are intrinsically linked to EBEN's objectives. The continuation of the organisation is fully dependent on the support of its stakeholders, and the objectives of the organisation are the same as the stakeholders'. Therefore, it can be argued that a non-profit network organisation can be viewed as an ultimate stakeholder organisation, where the organisation's and its stakeholders' objectives are intertwined, joint activities create value for all parties involved and the organisation practically exists through its stakeholders. This may, however, present risks for the organisation, such as when the stakeholders share similar goals with the organisation but favour different means of reaching these objectives.

\section{Managerial Implications}

The findings emphasise that a network organisation exists through its relationships with different stakeholders. This highlights the importance of identifying the best practices of each stakeholder in order to improve practices in the network as a whole. Creating and enhancing synergies and common goals are also imperative when the stakeholders of the NPO are homogeneous yet have considerable decision-making power in the organisation.

Stakeholders may perceive value in different ways. The value that can be created within a network organisation is mostly collective and intangible. It would be beneficial to 
evaluate what kinds of value each stakeholder appreciates and what kind of distribution of benefits is most useful among the network's stakeholders. For instance, in this case, stakeholder groups that are large in size aim for political influence, while smaller groups value the resources the network may provide to them.

Improving stakeholder engagement would benefit EBEN's value-creation processes. This could include communication and dialogue, which are important when striving to understand different stakeholders' interests and valuations. The practical implications could include, for instance, developing new platforms for members’ communication; this would benefit such a geographically widespread network. Moreover, online discussion forums could enable academic knowledge sharing; they could also be used in meetings and seminars. The organisation's transparency could be strengthened by providing more details of its internal meetings and strategic decisions to EBEN members.

\section{Limitations and Future Research}

This study is based on examining one case; therefore, the results are inevitably limited in their generalisability. However, the findings highlight some features of stakeholder engagement in NPOs that are likely to be generalisable to other similar NPOs and NGOs. Future research could examine other NPOs to further develop current theory from the following perspectives. In NPOs, stakeholder engagement is typically based on voluntary relationships - further empirical studies focusing on such relationships could contribute to understanding stakeholder engagement and management in NPOs and NGOs. Another focal aspect is related to value creation in stakeholder relationships; this has scarcely been addressed especially in NPOs and NGOs. 


\section{References}

Agudo-Valiente, J.M., Garcés-Ayerbe, C. and Salvador-Figueras, M. (2015) ‘Corporate social performance and stakeholder dialogue management', Corporate Social Responsibility and Environmental Management, Vol. 22 No. 1, pp. 13-31.

Alvesson, M. (2003) 'Beyond neopositivists, romantics, localists: A reflexive approach to interviews in organizational research', Academy of Management Review, Vol. 28 No. 1, pp. 13-33.

Arenas, D., Lozano, J.M. and Albareda, M. (2009) 'The role of NGOs in CSR. Mutual perceptions among stakeholders', Journal of Business Ethics, Vol. 88 No. 1, pp. 175197.

Boesso, G. and Kumar, K. (2009) 'An investigation of stakeholder prioritization and engagement: Who or what really counts', Journal of Accounting \& Organizational Change, Vol. 5 No. 1, pp. 62-80.

Bundy, J., Shropshire, C. and Buchholtz, A.K. (2013) 'Strategic coalition and issue salience: Toward an explanation of firm responsiveness to stakeholder concerns', Academy of Management Review, Vol. 38 No. 3, pp. 352-376.

Carroll, A. B. (2016) ‘Carroll’s pyramid of CSR: Taking another look’, International Journal of Corporate Social Responsibility, Vol. 1, No. 3, [online] http://jcsr.springeropen.com/articles/10.1186/s40991-016-0004-6 (Accessed 22 December 2016).

Clarkson, M. (1995) 'A stakeholder framework for analyzing and evaluating corporate social performance', Academy of Management Review, Vol. 20 No. 1, pp. 92-117.

Crane, A. and Ruebottom, T. (2011) 'Stakeholder theory and social identity: Rethinking stakeholder identification', Journal of Business Ethics, Vol. 102 No. 1, pp. 77-87. 
Dawkins, C.E. (2014) 'The principle of good faith: Toward substantive stakeholder engagement', Journal of Business Ethics, Vol. 121 No. 2, pp. 283-295.

Derry, R. (2012) 'Reclaiming marginalized stakeholders’, Journal of Business Ethics, Vol. 111 No. 2, pp. 253-264.

Donaldson, T. and Preston, L.E. (1995) 'The stakeholder theory of the corporation: Concepts, evidence, and implications', Academy of Management Review, Vol. 20 No. 1, pp. 6591.

Eisenhardt, K.M. (1989) ‘Building theories from case study research’, Academy of Management Review, Vol. 14 No. 4, pp. 532-550.

Elo, S. and Kyngäs, H. (2008) ‘The qualitative content analysis process’, Journal of Advanced Nursing, Vol. 62 No. 1, pp. 107-115.

Eriksson, P. and Kovalainen, A. (2016) Qualitative Methods in Business Research: A Practical Guide to Social Research, $2^{\text {nd }}$ ed., Sage, London.

Freeman, R.E. (1984) Strategic Management. A Stakeholder Approach, Pitman, Boston.

Freeman, R.E. (2010) 'Managing for stakeholders: Trade-offs or value creation', Journal of Business Ethics, Vol. 96 No. 1, pp. 7-9.

Freeman, R.E. and Evan, W.M. (1990) ‘Corporate governance: A stakeholder interpretation’, Journal of Behavioral Economics, Vol. 19 No. 4, pp. 337-359.

Freeman, R.E., Harrison, J.S., Wicks, A.C., Parmar, B.L. and de Colle, S. (2010) Stakeholder Theory: The State of the Art, Cambridge University Press, Cambridge.

Graneheim, U.H. and Lundman, B. (2004) 'Qualitative content analysis in nursing research: Concepts, procedures and measures to achieve trustworthiness', Nurse Education Today, Vol. 24 No. 2, pp. 105-112.

Greenwood, M. (2007) 'Stakeholder engagement: Beyond the myth of corporate responsibility’, Journal of Business Ethics, Vol. 74 No. 4, pp. 315-327. 
Harrison, J.S., Bosse, D.A. and Phillips, R.A. (2010) 'Managing for stakeholders, stakeholder utility functions, and competitive advantage’, Strategic Management Journal, Vol. 31 No. 1, pp. 58-74.

Harrison, J.S. and John, C.H.S. (1996) 'Managing and partnering with external stakeholders', The Academy of Management Executive, Vol. 10 No. 2, pp. 46-60.

Harrison, J.S. and Wicks, A.C. (2013) 'Stakeholder theory, value, and firm performance', Business Ethics Quarterly, Vol. 23 No. 1, pp. 97-124.

Hasnas, J. (2013) 'Whither stakeholder theory? A guide for the perplexed revisited', Journal of Business Ethics, Vol. 112 No. 1, pp. 47-57.

Heikkinen, A., Kujala, J. and Lehtimäki, H. (2013) 'Managing stakeholder dialogue: The case of Botnia in Uruguay', South Asian Journal for Business and Management Cases, Vol. 2 No. 1, pp. 25-37.

Hsieh, H-F. and Shannon, S. (2005) 'Three approaches to qualitative content analysis', Qualitative Health Research, Vol. 15 No. 9, pp. 1277-1288.

Kujala, J., Heikkinen, A. and Lehtimäki, H. (2012) 'Understanding the nature of stakeholder relationships: An empirical examination of a conflict situation', Journal of Business Ethics, Vol. 109 No. 1, pp. 53-65.

Kujala, J., Lämsä, A-M. and Riivari, E. (2017) ‘CSR as company stakeholder responsibility: Empirical evidence of top managers' attitudinal change', Baltic Journal of Management, Vol. 12 No. 2, pp. 114-138.

Laasonen, S. (2010). 'The role of stakeholder dialogue: NGOs and foreign direct investments', Corporate Governance: The International Journal of Business in Society, Vol. 10, No. 4, pp. 527-537. 
Leroux, K. (2009) 'Managing stakeholder demands: Balancing responsiveness to clients and funding agents in nonprofit social service organizations’, Administration \& Society, Vol. 41 No. 2, pp. 158-184.

Mahon, J.F., Heugens, P.P.M.A.R. and Lamertz, K. (2004) 'Social networks and nonmarket strategy’, Journal of Public Affairs, Vol. 4 No. 2, pp. 170-189.

Mainardes, E.W., Alves, H. and Raposo, M. (2012) 'A model for stakeholder classification and stakeholder relationships’, Management Decision, Vol. 50 No. 10, pp. 18611879.

Midtun, A., Gautesen, K. and Gjolberg, M. (2006) 'The political economy of CSR in Western Europe', Corporate Governance, Vol. 6 No. 4, pp. 369-385.

Mitchell, R.K., Agle, B.R. and Wood, D.J. (1997) 'Toward a theory of stakeholder identification and salience: Defining the principle of who and what really counts', Academy of Management Review, Vol. 22 No. 4, pp. 853-886.

Myllykangas, P., Kujala, J. and Lehtimäki, H. (2010) 'Analyzing the essence of stakeholder relationships: What do we need in addition to power, legitimacy and urgency?', Journal of Business Ethics, Vol. 96 No. 1, pp. 65-72.

Näsi, J. (1995) 'What is stakeholder thinking?’, in Näsi J. (Ed.), Understanding Stakeholder Thinking, LSR Publications, Helsinki, pp. 19-32.

Plaza-Úbeda, J.A., Burgos-Jiménez, J. and Carmona-Moreno, E. (2010) ‘Measuring stakeholder integration: Knowledge, interaction and adaptational behavior dimensions', Journal of Business Ethics, Vol. 93 No. 3, pp. 419-442.

Post, J.E., Preston, L.E. and Sachs, S. (2002) 'Managing the extended enterprise: The new

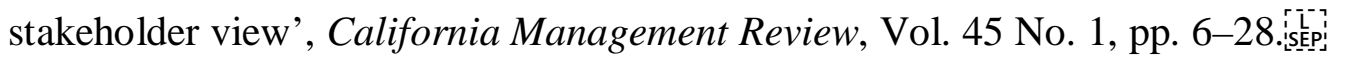

Roloff, J. (2008) 'Learning from multi-stakeholder networks: Issue-focussed stakeholder management', Journal of Business Ethics, Vol. 82 No. 1, pp. 233-250. 
Rowley, T.I. and Moldoveanu, M. (2003) ‘When will stakeholder groups act? An interestand identity-based model of stakeholder group mobilization', Academy of Management Review, Vol. 28 No. 2, pp. 204-219.

Sachs, S. and Rühli, E. (2011) Stakeholders Matter: A New Paradigm for Strategy in Society,

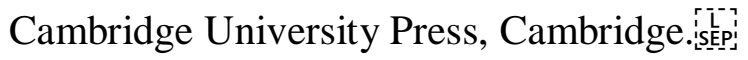

Savage, G.T., Nix, T.W., Whitehead, C.J. and Blair, J.D. (1991) 'Strategies for assessing and managing organizational stakeholders', Academy of Management Executive, Vol. 5 No. 2, pp. 61-75.

Schreier, M. (2014) 'Qualitative content analysis’, in Flick, U. (Ed.), The Sage Handbook of Qualitative Data Analysis, Sage, London, pp. 170-183.

Skouloudis, A., Evangelinos, K. and Malesios, C. (2015) 'Priorities and perceptions for corporate social responsibility: An NGO perspective’, Corporate Social Responsibility and Environmental Management, Vol. 22 No. 2, pp. 95-112.

Strand, R. and Freeman, R.E. (2015) 'Scandinavian cooperative advantage: The theory and practice of stakeholder engagement in Scandinavia', Journal of Business Ethics, Vol. 127 No. 1, pp. 65-85.

Wheeler, D., Colbert, B. and Freeman, R. E. (2003) 'Focusing on value: Reconciling corporate social responsibility, sustainability and a stakeholder approach in a network world', Journal of General Management, Vol. 28 No. 3, pp. 1-28.

Yin, R. (2009) Case Study Research: Design and Methods, Sage, Thousand Oaks, California. 


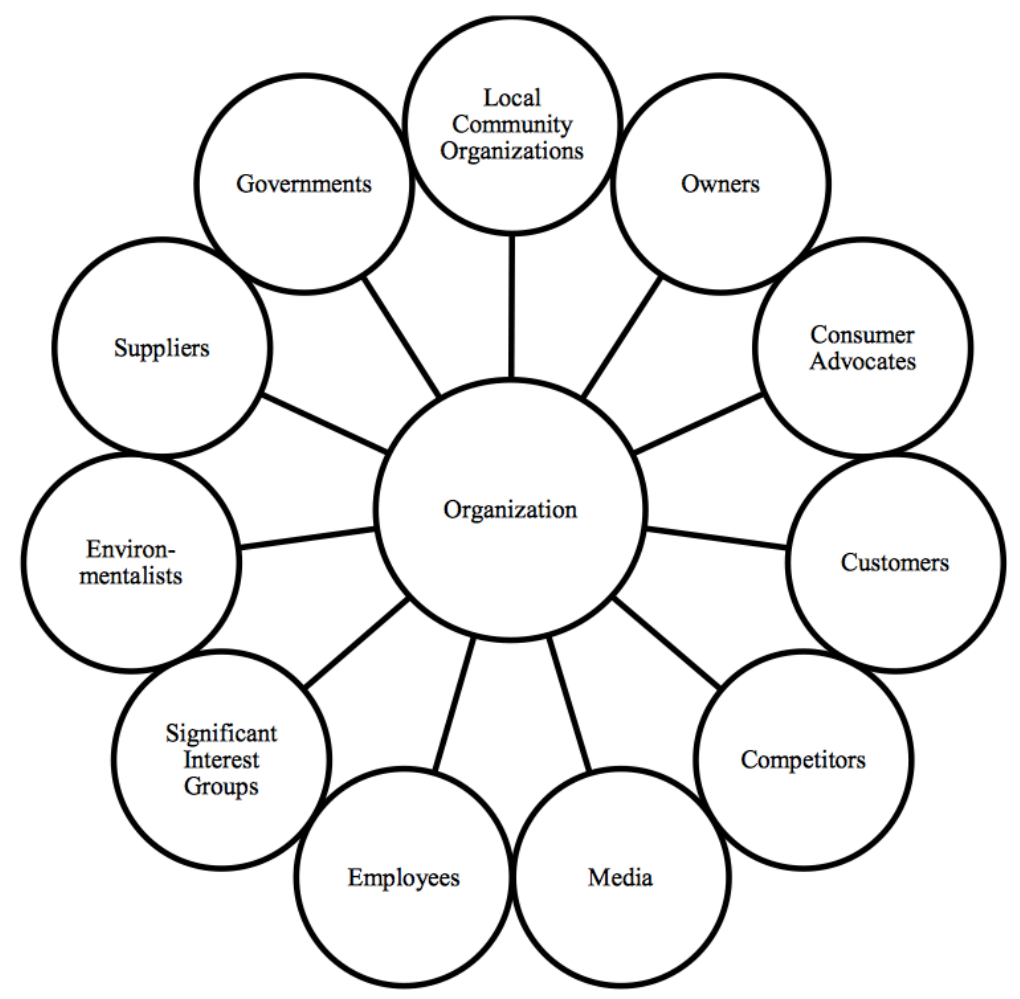

Figure 1. Stakeholder view of the firm (Freeman, 1984, p. 25).

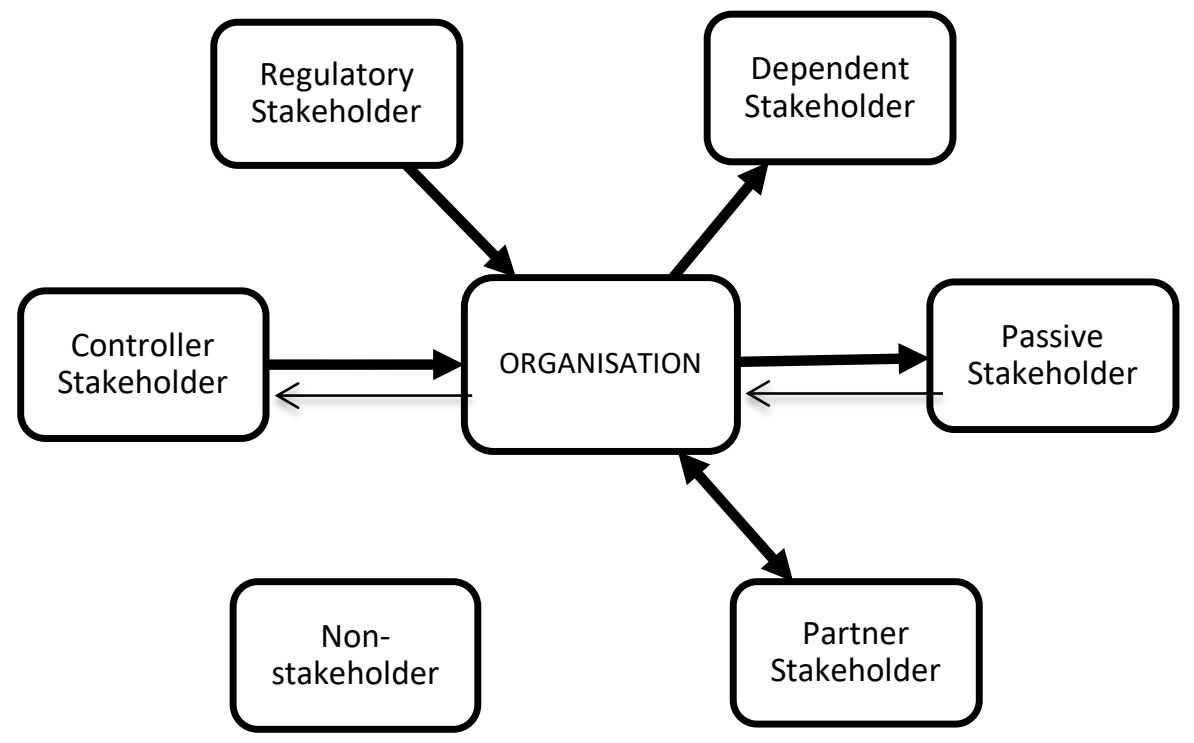

Figure 2. Stakeholder relationships in the public sector (Mainardes et al., 2012, p. 1874). 


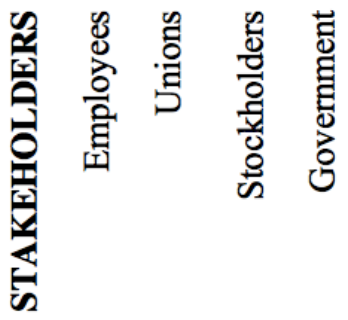

\section{ISSUES}

Product safety

$3 \quad 3$ NA 1

Truth in advertising

$1 \quad 1 \mathrm{NA} \quad 1$

Pricing policies

$3 \quad 3$ NA 1

Product service

3 3 NA 1

3 - high level of concern

2 - moderate level of concern

1 - low level of concern

NA - stakeholder is not concerned with the issue

Figure 3. Issue/stakeholder matrix (Freeman, 1984, p. 114). 


\begin{tabular}{|c|c|c|c|c|}
\hline & \multicolumn{3}{|c|}{$\begin{array}{l}\text { Relationship with the strategic frame } \\
\text { (instrumental salience) }\end{array}$} \\
\hline & & Consistent & Conflicting & Unrelated \\
\hline \multirow{3}{*}{$\begin{array}{l}\text { Relationship } \\
\text { with } \\
\text { organisational } \\
\text { identity } \\
\text { (expressive } \\
\text { salience) }\end{array}$} & Consistent & Substantive: & $\begin{array}{l}\text { Substantive: } \\
\text { Frame } \\
\text { conflict }\end{array}$ & $\begin{array}{l}\text { Symbolic: } \\
\text { Expressive } \\
\text { opportunity }\end{array}$ \\
\hline & Conflicting & $\begin{array}{l}\text { Substantive: } \\
\text { Identity } \\
\text { conflict }\end{array}$ & $\begin{array}{l}\text { Substantive: } \\
\text { True } \\
\text { threat }\end{array}$ & $\begin{array}{l}\text { Symbolic: } \\
\text { Expressive } \\
\text { threat }\end{array}$ \\
\hline & Unrelated & $\begin{array}{l}\text { Symbolic: } \\
\text { Instrumental } \\
\text { opportunity }\end{array}$ & $\begin{array}{l}\text { Symbolic: } \\
\text { Instrumental } \\
\text { threat }\end{array}$ & Nonissue \\
\hline
\end{tabular}

Table 1. The issue salience framework (Bundy, Shropshire and Buchholtz, 2013, p. 362). 


\begin{tabular}{|l|l|l|}
\hline Stakeholder & Actors in the Group & Influence Relationship \\
\hline National & $\begin{array}{l}\text { (a) Smaller networks } \\
\text { (b) Larger networks }\end{array}$ & $\begin{array}{l}\text { (a) Dependentišpép } \\
\text { (b) Controller/regulatory }\end{array}$ \\
\hline Members & Academics, students, & Controller \\
Similar & Anstitutions, companies & \\
organisations & Academy of Management & Controller/partner \\
\hline Other & Media, civil society, public & Various (depending on the \\
stakeholders & sector, schools, the EU & stakeholder) \\
\hline
\end{tabular}

Table 2. Summary and classification of EBEN's stakeholders (compiled by the authors). 


\begin{tabular}{|c|c|c|c|c|}
\hline \multirow[b]{2}{*}{ Issues } & \multicolumn{4}{|c|}{ Stakeholders } \\
\hline & Large NNs & $\begin{array}{l}\text { Small } \\
\text { NNs }\end{array}$ & $\begin{array}{c}\text { EBEN } \\
\text { members }\end{array}$ & $\begin{array}{c}\text { Similar } \\
\text { organisation } \\
\text { s }\end{array}$ \\
\hline Business ethics research & 3 & 3 & 3 & 3 \\
\hline Business ethics education & 2 & 2 & 3 & 3 \\
\hline Network as a social hub & 3 & 3 & 3 & 1 \\
\hline Financial stability & 2 & 3 & 2 & N/A \\
\hline Strengthening EBEN & 3 & 3 & 3 & N/A \\
\hline Ethical business conduct & 3 & 2 & 3 & 3 \\
\hline $\begin{array}{l}\text { Political impact and public } \\
\text { awareness }\end{array}$ & 3 & 2 & 1 & N/A \\
\hline $\begin{array}{l}3=\text { high level of concern } \\
2=\text { moderate level of conce } \\
1=\text { low level of concern }\end{array}$ & 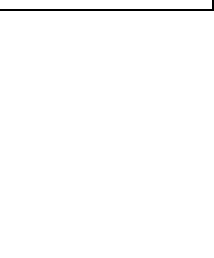 & & & \\
\hline $\mathrm{N} / \mathrm{A}=$ stakeholder is not $\mathrm{c}$ & h the issue & & & \\
\hline
\end{tabular}

Table 3. Issue/stakeholder matrix (compiled by the authors). 


\begin{tabular}{|c|c|c|c|c|}
\hline & \multicolumn{3}{|c|}{$\begin{array}{l}\text { Relationship with the strategic frame } \\
\text { (instrumental salience) }\end{array}$} \\
\hline & & Consistent & Conflicting & Unrelated \\
\hline \multirow[t]{3}{*}{$\begin{array}{l}\text { Relationship } \\
\text { with } \\
\text { organisational } \\
\text { identity } \\
\text { (expressive } \\
\text { salience) }\end{array}$} & Consistent & $\begin{array}{l}\text { True opportunity: } \\
\text { Business ethics } \\
\text { research, } \\
\text { Business ethics } \\
\text { education, } \\
\text { Network as social } \\
\text { hub }\end{array}$ & $\begin{array}{l}\text { Frame conflict: } \\
\text { Ethical business } \\
\text { conduct } \\
\text { Political impact and } \\
\text { public awareness }\end{array}$ & $\begin{array}{l}\text { Expressive } \\
\text { opportunity: } \\
\text { Not } \\
\text { identified }\end{array}$ \\
\hline & Conflicting & $\begin{array}{l}\text { Identity conflict: } \\
\text { Not identified }\end{array}$ & $\begin{array}{l}\text { True threat: } \\
\text { Not identified }\end{array}$ & $\begin{array}{l}\text { Expressive } \\
\text { threat: Not } \\
\text { identified }\end{array}$ \\
\hline & Unrelated & $\begin{array}{l}\text { Instrumental } \\
\text { opportunity: } \\
\text { Financial stability, } \\
\text { Strengthening EBEN }\end{array}$ & $\begin{array}{l}\text { Instrumental threat: } \\
\text { Not identified }\end{array}$ & $\begin{array}{l}\text { Nonissue: } \\
\text { Not } \\
\text { identified }\end{array}$ \\
\hline
\end{tabular}

Table 4. Salience of stakeholder-advocated issues (adapted from Bundy, Shropshire and Buchholtz, 2013). 